\title{
KEPEMILIKAN SERTIFIKASI KOMPETENSI DALAM SELEKSI FRONTLINERS BANK SYARIAH BUMN DI YOGYAKARTA
}

\author{
Nur Ellyanawati ER \\ Universitas Islam Indonesia \\ Jl. Kaliurang KM 14,5 Yogyakarta, Indonesia \\ Email : nur.ellyanawati@uii.ac.id
}

Received: 08 March, 2020; Revised: 24 March, 2020; Published: April 9, 2020

\begin{abstract}
ABSTRAK
Tujuan penelitian untuk mengetahui penerapan kepemilikan sertifikasi kompetensi dalam seleksi penerimaan frontliners perbankan untuk mendapatkan tenaga kerja yang kompeten. Hal ini dikarenakan saat ini pemerintah mendorong perbankan untuk lebih memprioritaskan tenaga kerja terampil. Perbankan dapat mensyaratkan kepemilikan sertifikasi kompetensi dalam proses penerimaan tenaga kerja. Metode penelitian deskriptif kualitatif dan analisa Chi-Square. Sampel yaitu Pimpinan Bank Syariah Mandiri Yogyakarta, Pimpinan BRI Syariah Yogyakarta, dan Pimpinan BNI Syariah Yogyakarta. Hasil penelitian menunjukkan terdapat hubungan antara kepemilikan sertifikasi kompetensi dengan seleksi penerimaan frontliners bank syariah. Penerimaan frontliners tahun 2019 belum mensyaratkan kepemilikan sertifikasi kompetensi. Namun pelamar yang memiliki sertifikat kompetensi lebih diprioritaskan karena memiliki manfaat yaitu mendapatkan tenaga kerja yang kompeten dan siap kerja, mengurangi biaya pelatihan tenaga kerja, bank dapat cepat mencapai target yang ditetapkan manajemen baik dalam hal jumlah rekening, layanan kepada nasabah, maupun target laba.
\end{abstract}

Kata Kunci: Penerimaan; Frontliners; Sertifikasi; Kompetensi.

\section{ABSTRACT}

The research objective is to determine the application of competency certification ownership in the selection of acceptance of banking frontliners to get a competent workforce. This is because the government is currently encouraging banks to prioritize skilled workers. Banks can require ownership of competency certification in the recruitment process. Descriptive qualitative research methods and Chi-Square analysis. The samples are the leadership of Bank Syariah Mandiri Yogyakarta, the leadership of BRI Syariah Yogyakarta, and the leadership of BNI Syariah Yogyakarta. The results showed there was a relationship between ownership of competency certification and selection of acceptance of Islamic bank frontliners. The acceptance of frontliners in 2019 does not require ownership of competency certification. However, applicants who have competency certificates are prioritized because they have the benefit of getting a competent and ready-to-work workforce, reducing labor training costs, banks can quickly reach the targets set by management both in terms of number of accounts, services to customers, and profit targets. 


\section{PENDAHULUAN}

Industri perbankan di Indonesia baik bank konvensional maupun bank syariah tumbuh semakin pesat seiring perkembangan aktivitas bisnis yang membutuhkan keberadaan bank untuk menunjang aktivitas bisnis tersebut dan semakin banyak kebutuhan masyarakat terhadap produk-produk dan layanan perbankan. Hal inilah yang dapat dilihat oleh perbankan sebagai peluang bisnis yang harus dikembangkan agar dapat meningkatkan layanan kepada nasabah dan sekaligus untuk dapat memenangkan persaingan bisnis bagi bank tersebut terhadap bank pesaing. Seiring dengan beragam dan meningkatnya produk-produk dan layanan, bank memerlukan tenaga kerja yang kompeten sehingga mampu memberikan kontribusi positif bagi kemajuan bank. Terdapat beberapa bidang profesi pekerjaan harus dipegang oleh staf yang secara professional terspesialisasi, serta andal supaya dapat menyelesaikan pekerjaan-pekerjaan di bidang tersebut (Mahmud, 2012). Tujuan lain perlu tenaga kerja yang kompeten adalah agar perusahaan dapat terus bersaing dan dapat melakukan pelayanan maksimal kepada konsumen (Wirjoatmodjo, 2017).

Karyawan yang berhubungan secara langsung dengan nasabah adalah bagian frontliners yaitu customer service dan teller. Frontliners secara langsung berinteraksi dengan nasabah, mulai dari menyampaikan informasi produk, pembukaan rekening, menangani keluhan nasabah, melayani setoran dan penarikan nasabah. Untuk dapat memberikan layanan yang prima kepada nasabah memerlukan keahlian khusus bagi frontliners sehingga nasabah dapat terlayani melampaui harapan mereka. Nasabah puas dengan layanan frontliners dan nasabah loyal kepada bank. Seiring dengan meningkatnya perkembangan transaksi di bank dan persaingan tenaga kerja maka secara alamiah bank akan mencari frontliners yang unggul dan dapat memenuhi kebutuhan bank (IBI, 2016).

Saat ini pemerintah Indonesia melalui Kemenakertrans telah mendorong perbankan untuk lebih memprioritaskan tenaga kerja terampil, sehingga akan lebih mudah menjalankan pekerjaan yang akan menjadi tugasnya. Menurut Yamu'alim (2015), perusahaan dapat menghemat biaya pelatihan yang biasanya diberikan untuk melatih tenaga kerja yang baru. Namun jika tenaga kerja yang dimiliki telah tersertifikasi kompetensi keahliannya hal ini dapat mengurangi biaya untuk pelatihan kerja. Sumber 
daya manusia di Indonesia sebaiknya terus ditingkatkan kualitasnya dan harus mendapatkan pengakuan kompetensi (Hapsari, 2016). BNSP merupakan lembaga mempunyai otoritas penyelenggara sertifikasi kompetensi bagi semua lini kompetensi di Indonesia, sehingga jika semua tenaga kerja di Indonesia telah memiliki sertifikasi hal ini bisa menjadi "barrier" terhadap masuknya tenaga asing di Indonesia. Untuk mendapatkan tenaga kerja yang kompeten, perbankan dapat mensyaratkan kepemilikan sertifikasi kompetensi dalam proses penerimaan tenaga kerja. Kompetensi keahlian karyawan ini harus ditunjukkan lisensinya yaitu melalui sertifikasi kompetensi. Menurut IBI (2016), dijelaskan bahwa sertifikasi kompetensi bisa diperoleh melalui mengikuti pelatihan kemudian mengikuti ujian sertifikasi kompetensi melalui LSP (Lembaga Sertifikasi Profesi). Sertifikasi Profesi bagi perbankan diselenggarakan oleh asosiasi perbankan yaitu LSPP (Lembaga Sertifikasi Profesi Perbankan) yang dibentuk dengan tujuan untuk menjadikan perbankan di Indonesia kokoh dan berdaya saing unggul termasuk untuk menghadapi resiko yang ada (Avrianingsih, 2016). LSPP membuat standar baku kompetensi kerja bagi para banker agar bisa mencapai kesetaraan dan meningkatkan profesional kerja. Sertifikasi kompetensi bidang layanan (frontliners) dapat melakukan uji kompetensi di LSPP dengan skema Customer Service dan Teller, dan apabila hasil yang diperoleh adalah kompeten, LSPP dapat memberikan gelar profesi dari BNSP secara langsung, yaitu gelar CCS (Certified Customer Service) dan CBT (Certified Banker Teller).

Bagi bank, pemenuhan atas kebutuhan karyawan frontliners perbankan yang kompeten dapat dimulai dari proses penerimaan karyawan. Bank dapat mencantumkan persyaratan kepemilikan sertifikasi kompetensi bagi karyawan frontliners (customer service dan teller) ke dalam peraturan perusahaan. Apabila ketentuan tersebut telah dibuat, maka bank dapat menerapkan peraturan perusahaan untuk mendapatkan karyawan yang kompeten. Namun apabila dalam peraturan perbankan belum ada ketentuan mewajibkan kepemilikan sertifikasi kompetensi keahlian, maka bank sebaiknya tetap memprioritaskan pelamar frontliners yang telah memiliki sertifikasi kompetensi, karena kompetensinya telah teruji baik secara teori maupun secara praktik (Murwati, 2013). 


\section{TINJAUAN PUSTAKA}

\section{Seleksi Penerimaan Karyawan (Frontliners)}

Seleksi merupakan proses memilih tenaga kerja untuk ditempatkan pada bagian-bagian atau unit-unit yang diperlukan oleh perusahaan (Sahaka, 2017). Tahapan seleksi penerimaan karyawan ini sangat penting karena untuk mencari kandidat terunggul dan berkualitas untuk mengemban jabatan. Perusahaan akan mendapatkan karyawan yang berkinerja tinggi dan berkualitas baik, presensi kehadirann tinggi dan mengunduran diri juga akan mengalami penurunan (Suwarsi, dkk, 2014). Ternyata karyawan yang telah memiliki kompetensi lebih berpeluang dipromosikan lebih cepat karena yang bersangkutan memiliki kompetensi teknis yang unggul (Prasetyo,2018). Sehingga beban-beban yang berkaitan dengan sumber daya manusia bisa dihemat. Setiap tahapan seleksi karyawan harus memegang prinsip yaitu "Right People on the Right Jobs" yaitu penempatan karyawan-karyawan secara tepat untuk posisi jabatan tertentu yang tepat.

Proses seleksi penerimaan karyawan meliputi tahapan-tahapan sebagai berikut (Sahaka, 2017): 1). Seleksi administrasi dan berkas lamaran, yaitu dengan meneliti berkas pelamar telah sesuai atau belum dengan persyaratan yang minimal harus dilengkapi; 2) Wawancara awal, tahapan ini dimaksudkan untuk menyaring pelamar yang memenuhi atau tidak memenuhi syarat yang ditentukan oleh perusahaan. Tahapan ini juga sekaligus dimaksudkan untuk menguji pengetahuan pelamar terhadap perusahaan yang dilamar; 3) Pengujian seleksi, meliputi pengujian kemampuan, pengujian ketrampilan teknis, tes minat, dan tes tulisan tangan; 4). Wawancara ketenagakerjaan, meliputi wawancara untuk menilai kemampuan percakapan formal, presentasi, focus group, dan diskusi; 5) Pemeriksaan latar belakang dan referensi, tahapan ini merupakan suatu proses untuk melakukan konfirmasi atau uji kebenaran terhadap informasi yang diberikan oleh pelamar. Pada tahapan ini biasanya bagian sumber daya manusia mencari informasi data-data pelamar kepada pihak-pihak yang terkait, misalnya dengan menghubungi atau mengirimkan permohonan informasi secara resmi ke pihak-pihak yang mengenal pelamar bahkan ke tempat kerja pelamar dahulu; 6) Evaluasi medis, bertujuan untuk memberikan kepastian mengenai kondisi kesehatan fisik pelamar secara medis oleh pihak yang berwenang. Hal ini dilakukan oleh perusahaan agar jika diterima sebagai karyawan baru di perusahaan dapat memberikan kontribusi yang maksimal sehingga dapat mengurangi ketidakhadiran pegawai, 
mengurangi biaya kesehatan pegawai, dan mengurangi biaya asuransi jiwa; 7) Keputusan seleksi, dilakukan setelah perusahaan mendapat data-data yang diperlukan mengenai pelamar, kemudian memutuskan penyeleksian. Dalam tahapan ini perusahaan memutuskan diterima atau tidaknya seorang pelamar. Namun ada juga tahapan tes yang menggunakan sistem gugur sehingga apabila ada pelamar yang tidak lolos di satu tahapan maka pelamar tersebut tidak akan dipanggil untuk mengikuti tahapan selanjutnya; 8) Surat pengangkatan (appointment letter), Pelamar yang telah dipilih menjadi karyawan baru dibuatkan surat keputusan pengangkatan.

\section{Frontliners}

Staf frontliners adalah petugas atau staf bank yang berada di posisi garis depan dalam melayani kebutuhan nasabah ( Rahmayanty, 2010). Staf Frontliners bank terdiri dari teller, customer service, satpam, dan supervisor layanan (IBI, 2016). Staf Teller adalah petugas yang melayani setoran, penarikan, kiriman uang, pemindahbukuan atau overbooking, penukaran uang atau yang berkaitan dengan transaksi keuangan nasabah. Staf Customer Service adalah petugas yang melayani nasabah dalam hal menjelaskan produk DPK, melayani pembukaan rekening, melayani pemesanan ATM, Internet Banking, Mobile Banking, SMS Banking, melayani atau menghandle komplain atau pengaduan nasabah, dan lain sebagainya.

\section{Kompetensi Keahlian}

Yamu'allim (2015) menjelaskan pasar tenaga kerja baik nasional maupun internasional menuntut ketersediaan tenaga kerja yang telah memiliki pengetahuan dan keterampilan. Hal ini disebabkan tenaga kerja merupakan modal utama untuk mencapai target-target yang ditetapkan oleh perusahaan baik swasta maupun pemerintah. Azmy (2015) menyatakan bahwa perkembangan keahlian teknis (kompetensi) untuk karyawan/staf perusahaan di setiap instansi ditujukan agar dapat mencapai tujuan organisasi yang telah ditetapkan secara berkesinambungan. Pengembangan dan perubahan organisasi harus dilakukan secara terus-menerus dan membutuhkan kompetensi seluruh karyawan. Perusahaan juga harus menyiapkan proses transfer pengetahuan agar kompetensi antar karyawan dapar seragam.

Efendi (2009) menyatakan bahwa kompetensi karyawan yang meliputi pengetahuan, keterampilan, dan sikap mempunyai pengaruh yang signifikan terhadap kinerja karyawan. Variabel kompetensi yang paling dominan 
berpengaruh terhadap kinerja karyawan adalah pengetahuan. Wahyudi, dkk (2014) dalam penelitiannya menyatakan kompetensi keahlian karyawan dalam suatu perusahaan sangat penting, karena dapat mendorong perusahaan untuk meningkatkan kinerja pegawai agar dapat memberikan kontribusi positif bagi perusahaan di masa depan. Kompetensi dapat pula cerminan kepribadian yang mendalam dan melekat pada seseorang dengan perilaku yang dapat diprediksi untuk menyelesaikan tugas-tugas pada situasi dan kondisi apapun.

Sesuai dengan Undang-Undang Ketenagakerjaan No. 13 tahun 2003 pasal 18 menyatakan bahwa setiap tenaga kerja berhak untuk mendapatkan pengakuan kompetensi kerja, dan dalam Pedoman Badan Nasional Sertifikasi (BNSP) No. 101-2005 batasan kompetensi kerja adalah kemampuan kerja setiap individu yang mencakup aspek pengetahuan, ketrampilan dan/atau keahlian serta sikap kerja yang sesuai dengan standar yang ditetapkan. Para pemegang sertifikat kompetensi ibaratnya telah memiliki Surat Ijin Mengemudi (SIM) untuk menjalankan profesinya, yaitu telah kompeten dalam sikap (attitude), penampilan (performance), dan pengetahuan (knowledge). Kompetensi sumber daya insani di bank syariah merupakan kombinasi antara kompetensi dasar perbankan dan nilai-nilai islami yang meliputi kemampuan memodifikasi produk dan layanan perbankan ke dalam prinsip syariah, memahami akadakad dalam bank syariah sehingga harapannya pasar bank syariah dapat bersaing dengan bank konvensional (Tho'in, 2016). Kompetensi mempengaruhi kualitas kinerja karyawan perbankan terutama dalam hal teknis pelayanan nasabah, oleh sebab itu setiap karyawan di bank sangat membutuhkan kepemilikan kompetensi teknis (Wulandari, 2018). Kompetensi karyawan yang minim (rendah) akan membuat komitmen dalam melaksanakan tugas juga tidak akan dapat berjalan maksimal terutama di bank adalah pelayanan kepada nasabah (Shaputra, 2015).

\section{Sertifikasi Kompetensi}

Sertifikasi kompetensi adalah proses untuk memberikan pengakuan secara tertulis atas keahlian yang dilakukan secara sistematis dan objektif melalui uji kompetensi yang mengacu pada standar kompetensi kerja yang bersifat nasional maupun (Saskiawardani, 2009). Sertifikasi kompetensi memiliki peranan yang paling penting bagi Lembaga keuangan, karena diperlukan untuk mengukur kapasitas dan kapabilitas tenaga kerja yang menjalankan bisnis di bidang keuangan (Erman, 2017). 
Alvionita (2018) menjelaskan bahwa sertifikasi kompetensi merupakan kebijakan yang dibuat pemerintah untuk peningkatan kompetensi keahlian karyawan di Indonesia. Sertifikasi kompetensi dapat dimanfaatkan untuk mempercepat karier pegawai, kinerja pegawai, dan kompetisi diantara karyawan lainnya.

Tujuan sertifikasi kompetensi adalah sebagai berikut (Jauhari, 2009) : 1) Membantu karyawan yang memiliki profesi kompetensi tertentu untuk memberi kepastian kepada perusahaan bahwa karyawan tersebut memiliki kompetensi dalam pekerjaannya; 2) Kompetensi keahlian untuk meningkatkan rasa percaya diri; 3) Mendukung karyawan yang memiliki kompetensi keahlian untuk merencanakan karirnya; 4) Membantu mengukur secara pasti capaian kompetensi keahlian baik secara formal maupun non formal; 5) Memudahkan karyawan yang berprofesi untuk mancapai kualifikasi yang harus dipenuhi; 6)

Manfaat bagi profesional pemegang sertifikat kompetensi sebagai berikut (Triana, 2017) : 1) Dapat memilih program sertifikat kompetensi kerja sesuai bidang profesi yang dipilih dan meningkatkan akses untuk berkembang; 2) Memudahkan dalam meyakinkan atas kompetensi kerja yang dimiliki kepada perusahaan / industri dan jenjang karir yang lebih baik; 3) Meningkatkan nilai jual sesuai profesi yang telah dipilih; 4) Meningkatkan kepercayaan diri dalam menjalankan profesinya dan berkompetensi di pasar tenaga kerja.

Manfaat sertifikasi kompetensi bagi perusahaan/industri sebagai berikut (Triana, 2017) : 1) Memudahkan dalam menyusun job description, materi pelatihan/training yang diperlukan dan penilaian kinerja; 2) Sebagai salah satu faktor penting dalam rangka recruitment, mutasi dan promosi; 3) Pegawai yang kompeten, perusahaan dapat meningkatkan efisiensi dan mampu bersaing dengan pesaing bisnisny; 4) Meningkatkan loyalitas pegawai kepada perusahaan atau profesinya.

Budiman (2018) dalam penelitiannya menyatakan terdapat peranan antara sertifikasi guru secara signifikan terhadap pencapaian kinerja guru, sehingga sebaiknya pihak yang memiliki kepentingan dengan pelaksanaan pendidikan dan juga bagi pemerintah agar dapat melakukan perbaikan dan meningkatkan kualitas kesejahteraan guru. Hal ini sebagai bentuk apresiasi terhadap setiap kemajuan kinerja dan prestasi yang telah dicapai oleh guru.

Mahdane, A (2018) dalam penelitiannya Pengaruh Standar Kompetensi Kerja Nasional Indonesia dan kompetensi sumber daya manusia terhadap 
pengembangan SDM di unit profesi SDM dalam menghadapi MEA menyatakan bahwa Standar Kompetensi Kerja Nasional Indonesia tidak memiliki pengaruh nyata terhadap kompetensi dan pengembangan sumber daya manusia, tetapi berpengaruh terhadap kebijakan-kebijakan perusahaan.

Silitonga (2007), dalam penelitiannya menjelaskan bahwa sistem sertifikasi di Indonesia untuk dosen dan tenaga kerja lainnya merupakan sarana pengakuan atas kompetensi yang telah dimiliki baik melalui pendidikan dan pelatihan maupun pengalaman kerja. Standar kualifikasi nasional yang ditetapkan oleh para pemangku kepentingan industri bekerja sama dengan sektor terkait di pemerintah pusat dan kemudian Kementerian Tenaga Kerja menetapkan sebagai standar kompetensi kerja nasional. Berdasarkan standar, pusat-pusat pelatihan akan mengadakan pelatihan berbasis kompetensi baik di dalam maupun di organisasi pelatihan yang terakreditasi (Martina, 2012). BNSP dan Departemen Pendidikan dapat bekerja sama untuk membentuk Badan Sertifikasi Profesi untuk dosen berdasarkan Peraturan Pemerintah No. 19 tahun 2005 tentang Standar Pendidikan Nasional sesuai dengan Peraturan Pemerintah No. 23 tahun 2004 tentang Otoritas Sertifikasi Profesional Indonesia. Oleh karena itu, BNSP direkomendasikan untuk memperluas kewenangannya untuk mengakses lembaga pelatihan untuk didaftarkan/terakreditasi organisasi pelatihan untuk menjamin bahwa standarstandar tersebut ada dan diterapkan oleh mereka melalui Hukum Negara di samping Peraturan Pemerintah No. 23 tahun 2004.

\section{Pembaruan}

Dari penelitian-penelitian terdahulu yang telah dilakukan, peneliti mengambil pembaruan penelitian yang mengaitkan penerapan kepemilikan sertifikasi kompetensi dalam seleksi penerimaan frontliners bank syariah di Yogyakarta. Hubungan antara kepemilikan sertifikasi kompetensi dengan seleksi penerimaan frontliners bank syariah, serta manfaat-manfaat yang diperoleh bagi bank syariah jika menerima karyawan baru yang telah memiliki sertifikasi kompetensi. 


\section{METODE PENELITIAN}

Penelitian ini menggunakan deskriptif-kualitatif serta data-data pendukung seperti literatur dan sebagainya, kemudian diuji hubungan antar variabel dengan menggunakan Chi Square. Sumber data diperoleh dalam penelitian ini melalui sumber data primer dan data sekunder. Populasi yang digunakan dalam penelitian ini adalah seluruh pemimpin (Branch Manager atau Operational Manager) Bank Syariah di wilayah Yogyakarta. Sedangkan sampel yang diambil pada penelitian ini adalah seluruh pemimpin Bank Syariah Anak Perusahaan Bank BUMN dan Bank Syariah Unit Usaha Syariah Bank BUMN yang memiliki Kantor Cabang di Yogyakarta yaitu Bank BNI Syariah Cabang Yogyakarta, Bank BRI Syariah Cabang Yogyakarta, Bank BTN Syariah Cabang Yogyakarta, dan Bank Syariah Mandiri Cabang Yogyakarta (tidak termasuk layanan Syariah Chanelling Outlet. Analisis data adalah chi square untuk mengukur hubungan antara kepemilikan sertifikasi dan kompetensi keahlian terhadap penerimaan karyawan dan kinerja karyawan. Analisa chi square dipilih dalam penelitian ini karena menggunakan data non parametrik atau data yang tidak berdistribusi normal (tanpa asumsi populasi berdistribusi normal), sehingga untuk mengukur hubungan antara kepemilikan sertifikasi dan kompetensi keahlian terhadap penerimaan karyawan dan kinerja karyawan yang paling tepat menggunakan chi square. Ada 2 uji chi square, yaitu 1) Uji goodness of fit : menguji perbedaan antara frekuensi yang diobservasi dan frekuensi yang diharapkan. 2) Uji tabel kontinjensi : menguji hubungan dua variabel independen dengan skala nominal.

\section{HASIL PENELITIAN DAN PEMBAHASAN}

Hasil interview atau wawancara dengan pejabat bank syariah di Yogyakarta diketahui bahwa pada bulan Januari sampai dengan Desember 2019 seluruh bank syariah yang menjadi sampel penelitian melakukan penerimaan karyawan baru untuk posisi frontliners. Bank BNI Syariah KC Yogyakarta ( Arif, Operasional Manager) merekrut karyawan baru sebanyak 7 orang untuk posisi teller. Bank BRI Syariah Kantor Cabang Yogyakarta (Kurniawan, Branch Manager) merekrut karyawan baru sebanyak 13 orang, untuk posisi customer service 2 orang dan teller 11 orang. Bank Syariah Mandiri 
Kantor Cabang Yogyakarta (Khoerul Wajid, Branch Manager) merekrut karyawan baru sebanyak 6 orang, untuk posisi teller semua. Total bank syariah di Yogyakarta yang menjadi sampel penelitian pada tahun 2019 melakukan penerimaan karyawan baru untuk posisi frontliners sebanyak 26 orang.

Tabel 1 Jumlah Penerimaan Karyawan Baru (Frontliners) Bank Syariah di Yogyakarta Tahun 2019

\begin{tabular}{l|l|l|l}
\hline No & \multicolumn{1}{|c|}{ Nama bank syariah } & Customer service & \multicolumn{1}{c}{ Teller } \\
\hline 1 & Bank BNI Syariah KC Yogyakarta & 0 & 7 \\
\hline 2 & Bank BRI Syariah KC Yogyakarta & 2 & 11 \\
\hline 3 & Bank Syariah Mandiri KC Yogyakarta & 0 & 6 \\
\hline & TOTAL & 2 & 24 \\
\hline
\end{tabular}

Sumber: Hasil wawancara dengan pejabat bank syariah

\section{Persyaratan Kepemilikan Sertifikasi Kompetensi dalam Penerimaan} Frontliners

Persyaratan penerimaan karyawan baru untuk frontliners di bank syariah Yogyakarta dipublikasikan melalui pengumuman di kantor bank, pengumuman di media massa, dan pengumuman di website bank tersebut. Bank syariah secara keseluruhan $(100 \%)$ belum mencantumkan persyaratan kepemilikan sertifikasi kompetensi di dalam persyaratan penerimaan karyawan baru. Hal ini menurut wawancara dengan pejabat bank syariah tersebut dikarenakan belum ada ketentuan dari kantor pusat bank tersebut yang mewajibkan pelamar kerja harus memiliki sertifikasi kompetensi keahlian.

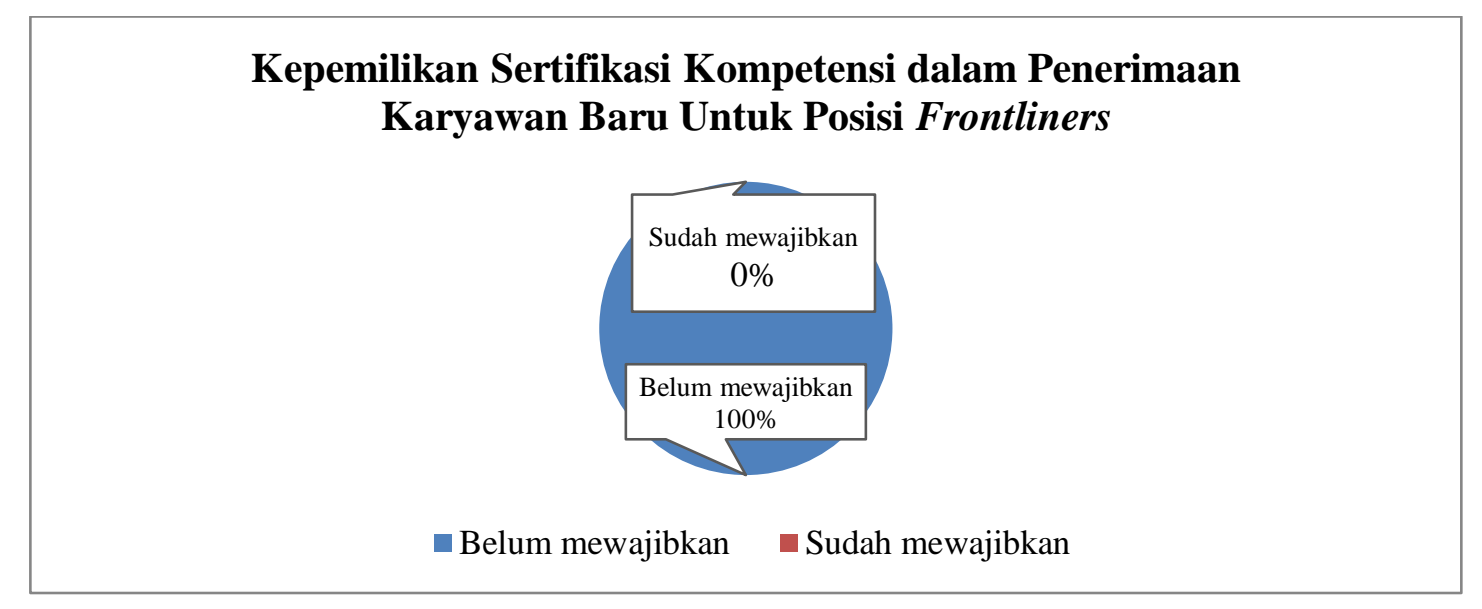

Gambar 1. Kepemilikan Sertifikasi Kompetensi dalam Penerimaan Karyawan Baru untuk Posisi Frontliners 


\section{Jumlah Frontliners Baru di Bank Syariah Yogyakarta Yang Diterima dan Memiliki Sertifikasi Kompetensi Keahlian}

Hasil penerimaan karyawan baru frontliners Bank Syariah BUMN di Yogyakarta walaupun pihak bank belum mensyaratkan kepemilikan sertifikasi kompetensi, namun ternyata terdapat pelamar kerja yang memiliki sertifikasi kompetensi untuk posisi customer service dan teller. Beberapa dari pelamar ternyata telah memiliki gelar Certified Customer Service dan Certified Banker Teller.

Jumlah pelamar kerja di Bank BNI Syariah Cabang Yogyakarta untuk posisi frontliners terdapat sejumlah 164 orang pelamar. Jumlah pelamar tersebut terdapat 6 diantaranya yang telah memiliki sertifikasi kompetensi keahlian dan pelamar tersebut diterima sebagai karyawan frontliners untuk posisi jabatan teller. Berarti dapat dijelaskan bahwa pelamar yang memiliki sertifikasi kompetensi keahlian dan diterima sebagai karyawan prosentasenya $100 \%$. Perbandingan pelamar bersertifikasi yang diterima sebagai frontliners dibandingkan pelamar yang diterima sebagai frontliners namun yang tidak bersertifikat adalah sebesar $85,71 \%$.

Jumlah pelamar kerja di Bank BRI Syariah Cabang Yogyakarta untuk posisi frontliners terdapat sejumlah 102 orang pelamar. Jumlah pelamar tersebut terdapat 9 diantaranya yang telah memiliki sertifikasi kompetensi keahlian dan pelamar yang memiliki sertifikasi kompetensi keahlian tersebut seluruhnya dapat diterima sebagai karyawan frontliners untuk posisi jabatan teller. Berarti dapat dijelaskan bahwa pelamar yang memiliki sertifikasi kompetensi keahlian dan diterima sebagai karyawan prosentasenya 100\%. Perbandingan pelamar bersertifikasi yang diterima sebagai frontliners dibandingkan pelamar yang diterima sebagai frontliners namun yang tidak bersertifikat adalah sebesar $69,23 \%$.

Jumlah pelamar kerja di Bank Syariah Mandiri Cabang Yogyakarta untuk posisi frontliners terdapat sejumlah 145 orang pelamar. Jumlah pelamar tersebut terdapat 3 diantaranya yang telah memiliki sertifikasi kompetensi keahlian dan pelamar yang memiliki sertifikasi kompetensi keahlian tersebut seluruhnya dapat diterima sebagai karyawan frontliners untuk posisi jabatan teller. Berarti dapat dijelaskan bahwa pelamar yang memiliki sertifikasi kompetensi keahlian dan diterima sebagai karyawan prosentasenya $100 \%$. Perbandingan pelamar bersertifikasi yang diterima sebagai frontliners 
dibandingkan pelamar yang diterima sebagai frontliners namun yang tidak bersertifikat adalah sebesar 50,00\%.

Tabel 2. Perbandingan antara Pelamar yang Bersertifikasi Kompetensi dan Pelamar yang Belum Bersertifikasi Kompetensi.

\begin{tabular}{l|l|l|l|l|l|l|l}
\hline Bank & $\begin{array}{l}\text { Pela } \\
\text { mar } \\
\text { FL }\end{array}$ & $\begin{array}{l}\text { Pelamar } \\
\text { FL } \\
\text { Bersertif } \\
\text { ikasi }\end{array}$ & $\begin{array}{l}\text { Pelamar } \\
\text { FL Tidak } \\
\text { Bersertifik } \\
\text { asi }\end{array}$ & $\begin{array}{l}\text { Pelamar FL } \\
\text { Bersertifika } \\
\text { si yang } \\
\text { Diterima }\end{array}$ & $\begin{array}{l}\text { Pelamar FL } \\
\text { Tidak } \\
\text { Bersertifika } \\
\text { si Namun } \\
\text { Diterima }\end{array}$ & $\begin{array}{l}\text { Pelamar } \\
\text { Bersertifikasi } \\
\text { Yang } \\
\text { Diterima }\end{array}$ & $\begin{array}{l}\text { Pelamar } \\
\text { Yang Diterima } \\
\text { (Bersertifikasi } \\
\text { Dibanding } \\
\text { Yang Tidak } \\
\text { Bersertifikasi) }\end{array}$ \\
\hline BNIS YK & 164 & 6 & 158 & 6 & 1 & $100 \%$ & $85,71 \%$ \\
\hline BRIS YK & 102 & 9 & 93 & 9 & 4 & $100 \%$ & $69,23 \%$ \\
\hline BSM YK & 145 & 3 & 142 & 3 & 3 & $100 \%$ & $50,00 \%$ \\
\hline
\end{tabular}

Sumber: Data diolah dari Bank Objek Penelitian

Hasil tabel tersebut dapat menjelaskan bahwa walaupun belum tertuang dalam peraturan perusahaan bahwa kepemilikan sertifikasi kompetensi menjadi salah satu persyaratan dalam penerimaan karyawan baru, namun dari hasil wawancara dengan pejabat bank syariah yang menjadi sampel penelitian menyebutkan bahwa mereka lebih memprioritaskan pelamar yang telah memiliki sertifikasi kompetensi keahlian. Hal ini juga terbukti dari jumlah pelamar yang memiliki sertifikasi kompetensi semuanya (100\%) diterima sebagai karyawan baru. Tahapan tes yang dilakukan perusahaan tersebut disampaikan bahwa pelamar yang bersertifikasi kompetensi ternyata hasil penilaiannya lebih unggul dibanding pelamar yang tidak bersertifikasi.

Para pelamar tersebut dapat membuktikan kemampuan dirinya dan dapat menyelesaikan tahapan tes teori maupun praktik dengan lebih baik, terlihat telah menguasai materi dan terampil, sehingga pelamar yang memiliki sertifikasi kompetensi lebih layak untuk diterima sebagai karyawan. Pelamar yang memiliki sertifikasi kompetensi tersebut berasal dari Fakultas Ekonomi dari berbagai Perguruan Tinggi baik dari Diploma III maupun dari jenjang S1. Sedangkan pelamar yang belum tersertifikasi ada yang berasal dari Fakultas Ekonomi maupun berasal dari bidang keilmuan lain (non Ekonomi). Pelamar yang memiliki sertifikasi kompetensi menurut pejabat bank syariah telah mendapat informasi dari kampus asal pelamar dan didorong oleh pihak kampus untuk mengikuti sertifikasi tersebut. Bagi akademisi sangat didorong agar dalam kurikulum pendidikannya salah satumya mencantumkan program sertifikasi kompetensi keahlian sesuai bidang atau profil lulusan. Hal ini sangat 
penting dan telah terbukti bahwa ketika lulusan mahasiswa dibekali dengan kepemilikan kompetensi (tidak cukup hanya ijazah), ternyata hasil yang diperoleh juga dapat membantu memudahkan lulusan untuk lebih bersaing dan unggul di dunia kerja.

Pejabat bank syariah di Yogyakarta mendukung jika kepemilikan sertifikasi dapat dituangkan dalam persyaratan penerimaan pegawai baru. Bagi pihak perusahaan hal ini sangat menguntungkan, karena perusahaan akan mendapatkan tenaga kerja yang terampil dan telah menguasai pekerjaan baik secara teori maupun secara praktek. Bahkan ketika diminta untuk melakukan analisa terhadap suatu kasus, para pelamar kerja yang memiliki kompetensi ini menurut Pejabat Bank Syariah yang menjadi sampel penelitian menjelaskan bahwa mampu menganalisa kasus yang diberikan dengan menggabungkan teori dan alternatif-alternatif solusi. Biaya pelatihan tenaga kerja baru juga dapat ditekan karena tenaga yang direkrut telah menguasai praktik kerja di perbankan dan kebutuhan pelatihan tidak membutuhkan waktu lama serta biaya besar. Tenaga kerja baru hanya memerlukan refreshment product knowledge dan penyesuaian dengan software atau aplikasi yang digunakan oleh bank.

Tenaga frontliners baru yang diterima oleh bank dan memiliki sertifikasi kompetensi telah mengetahui tugas, tanggung jawab dan wewenang dari job desk di bagian layanan nasabah. Penampilan dalam bekerja sesuai dengan kertas kerja layanan perbankan di Indonesia sudah diterapkan dengan baik pada saat tahapan seleksi pegawai, produk-produk perbankan juga telah dikuasai, skill melayani nasabah baik di customer service ataupun di teller telah dipahami dan bisa dipraktekkan dengan cepat dan tepat sehingga dapat memudahkan bank dalam operasional kerja sehari-hari. Tahapan-tahapan dalam setiap seleksi dilalui oleh pelamar yang memiliki kompetensi dengan lebih baik dan unggul baik secara teori maupun secara praktek dibanding dengan peserta lain yang belum memiliki kompetensi. Hal inilah yang juga menurut pejabat bank syariah di Yogyakarta lebih mempertimbangkan memilih menerima karyawan baru yang telah memiliki kompetensi.

\section{Analisa Chi Square}

Dari uraian yang telah dijelaskan di atas, dilakukan perhitungan datadata menggunakan analisa statistik Chi Square. Analisa ini dipergunakan untuk menguji hubungan antara kepemilikan sertifikasi kompetensi terhadap seleksi penerimaan pegawai frontliners bank syariah BUMN di Yogyakarta.

Rumus perhitungan yang digunakan dalam Chi Square : 


$$
\begin{aligned}
& \chi^{2}=\sum\left[\frac{\left(f_{o}-f_{e}\right)^{2}}{f_{e}}\right] \\
& f_{e}=\frac{(\text { total frekuensi baris)(total frrkuensi kolom) }}{\text { (total baris dan kolom) }}
\end{aligned}
$$

Dengan menggunakan derajat kepercayaan, $\alpha=5 \%$,

Maka: Nilai $\chi^{2}$ kritis dengan $\alpha=5 \%$ dan df (b-1) $(k-1)=((3-1)(4-1)=6$

\begin{tabular}{|c|c|c|c|c|c|c|c|c|c|c|}
\hline \multirow[t]{2}{*}{$\begin{array}{l}\text { Bank } \\
\text { BUMN } \\
\text { Syariah } \\
\text { di YK }\end{array}$} & \multicolumn{2}{|c|}{$\begin{array}{l}\text { Pelamar } \\
\text { Punya } \\
\text { Sertifikasi }\end{array}$} & \multicolumn{2}{|c|}{$\begin{array}{l}\text { Pelamar } \\
\text { Tidak } \\
\text { Punya } \\
\text { Sertifikasi }\end{array}$} & \multicolumn{2}{|c|}{$\begin{array}{l}\text { Pelamar } \\
\text { Diterima } \\
\text { Punya } \\
\text { Sertifikasi }\end{array}$} & \multicolumn{2}{|c|}{$\begin{array}{l}\text { Pelamar } \\
\text { Diterima } \\
\text { Tdk Punya } \\
\text { Sertifikasi }\end{array}$} & \multicolumn{2}{|c|}{ Total } \\
\hline & $\mathrm{Fe}$ & fo & $\mathrm{fe}$ & fo & $\mathrm{fe}$ & Fo & $\mathrm{fe}$ & fo & $\mathrm{fe}$ & fo \\
\hline BNIS & 6 & 7.043 & $\begin{array}{l}15 \\
8\end{array}$ & $\begin{array}{l}153.78 \\
3\end{array}$ & 6 & 7.043 & 1 & 3.130 & 171 & 171 \\
\hline BRIS & 9 & 4.737 & 93 & $\begin{array}{l}103.42 \\
1\end{array}$ & 9 & 4.737 & 4 & 2.105 & 115 & 115 \\
\hline BSM & 3 & 6.220 & $\begin{array}{l}14 \\
2\end{array}$ & $\begin{array}{l}135.79 \\
6\end{array}$ & 3 & 6.220 & 3 & 2.764 & 151 & 151 \\
\hline Total & 18 & 18 & $\begin{array}{l}39 \\
3\end{array}$ & 393 & 18 & 18 & 8 & 8 & 437 & 437 \\
\hline \multicolumn{11}{|c|}{$(6-7.043)^{2} \quad(158-153.783)^{2}$} \\
\hline$=\frac{7.0}{7.0}$ & $\begin{array}{r}3+ \\
+\end{array}$ & $\begin{array}{r}1 \\
\frac{(93-1}{103} \\
\frac{(142-}{13}\end{array}$ & $\begin{array}{l}3.78 \\
3.42 \\
421 \\
35.7 \\
.796\end{array}$ & $\frac{)^{2}}{6)^{2}}+$ & $\begin{array}{r}7.0 \\
(9-4 \\
4.7 \\
-6 . \\
6.22\end{array}$ & $\begin{array}{l}3 \\
\frac{37)^{2}}{7}+ \\
0)^{2}+(\end{array}$ & $\begin{array}{r}3 \\
(4- \\
2 \\
3-2 \\
2.7\end{array}$ & $\begin{array}{l}\frac{305)^{2}}{05}+ \\
\frac{.64)^{2}}{4}\end{array}$ & $\begin{array}{r}4 \\
\frac{(3-}{6}\end{array}$ & $\frac{37}{220)^{2}}$ \\
\hline \multicolumn{11}{|c|}{$\begin{array}{l}=0.155+0.116+0.155+1.450+3.837+1.050+3.837+1.705+1.667+0.283 \\
+1.667+0.020\end{array}$} \\
\hline
\end{tabular}
sebesar 12.591

Kesimpulan: $\chi^{2}$ hitung $>\chi^{2}$ kritis, yaitu $15.941>12.591$ yang artinya menolak hipotesi Ho, menerima hipotesi Ha. Berarti terdapat hubungan antara kepemilikan sertifikasi kompetensi dengan seleksi penerimaan frontliners di Bank Syariah BUMN di Yogyakarta. 


\section{SIMPULAN}

Terdapat hubungan antara kepemilikan sertifikasi kompetensi dengan seleksi penerimaan frontliners di Bank Syariah BUMN di Yogyakarta. Seluruh pelamar frontliners yang memiliki sertifikasi kompetensi diterima sebagai karyawan baru. Pemimpin bank syariah di Yogyakarta yang menjadi sampel penelitian menyebutkan bahwa di perusahaannya belum mewajibkan dalam penerimaan karyawan baru memiliki sertifikasi kompetensi, namun apabila calon pegawai tersebut telah memiliki sertifikasi kompetensi profesi maka perusahaan akan lebih memprioritaskan dalam seleksi karyawan baru. Dalam tahapan tes yang dilakukan oleh perusahaan diketahui bahwa pelamar yang bersertifikasi kompetensi hasil penilaiannya lebih unggul dibanding pelamar yang tidak bersertifikasi. Para pelamar tersebut dapat menyelesaikan tahapan tes teori maupun praktik dengan lebih baik, terlihat telah menguasai materi, dan terampil. Ketika tenaga kerja baru tersebut memulai kerja dalam masa on the job training atau masa percobaan, tenaga kerja tersebut lebih cepat beradaptasi dengan pekerjaannya dan mampu menyelesaikan job desk yang menjadi tugasnya dengan baik dan memuaskan. Hal ini terlihat secara nyata menunjukkan bahwa kepemilikan sertifikasi kompetensi sangat penting dan menguntungkan baik bagi pelamar kerja, perusahaan, dan bahkan bagi dunia pendidikan yang menghasilkan lulusan yang unggul dan siap kerja. 


\section{DAFTAR PUSTAKA}

Alvionita, V (2018), Persepsi Karyawan Hotel terhadap Manfaat Sertifikasi Kompetensi Pariwisata Bidang Perhotelan Di Kota Bandung, Journal of Indonesian Tourism and Recreation, Vol. 1, No. 2.

Atallah (2013), The Impact of Knowledge Management Functions on the Organizational Excellence from the Perspective of the University of Al-Taif Staff, Interdiciplinary Journal Of Contemporary Research In Business, Vol. 5, No.3 : 172-192.

Avrianingsih, S (2016), Arsitektur Sistem Informasi Lembaga Sertifikasi (Studi Kasus Sertifikasi Profesi Perbankan dan Sistem Pengendalian Online Sertifikasi Kompetensi pada Badan Nasional Sertifikasi Profesi, Indonesian Journal on Networking and Security, Vol. 5, No. 1.

Azmy, A (2015), Pengembangan Kompetensi Sumber Daya Manusia Untuk Mencapai Career Ready Profesional di Universitas Tantri Abeng, Jurnal Binus Business Review, Vol. 6, No. 2 : 220-232.

Budiman (2018), Peranan Penerapan Sertifikasi Guru Terhadap Kinerja Guru (Integrasi Psikologi Industri dan Organisasi Islami), Jurnal Psikologi Islami, Vol. 4, No. 1 : 74-81.

Efendi (2009), Pengaruh Kompetensi Terhadap Kinerja Karyawan Pada Kantor Pelayanan Pajak Metro, Fakultas Ekonomi, Universitas Muhammadiyah Lampung.

Erman (2017), Standar Kompetensi Pengelola Koperasi Simpan Pinjam Syariah Di BMT Taqwa Muhammadiyah Padang, Jurnal Kajian Ekonomi Islam, Vol. 2, No. 2 : 193-203.

Hapsari, M, (2016), Pengkajian Program Kursus dan Pelatihan Terkait dengan Jenis Ketrampilan, Sertifiksi dan Penempatan Lulusan, Journal of Nonformal Education, Vol. 2, No. 1.

Ikatan Bankir Indonesia (2016), Mengelola Kualitas Layanan Perbankan, Jakarta, PT Gramedia Pustaka Utama.

Jauhari, T (2009), Mengasah Kompleksitas Kompetensi Melalui Sertifikasi, Ikatan Bankir Indonesia, Jakarta. 
Mahdane, A (2018), Pengaruh SKKNI dan Kompetensi SDM terhadap Pengembangan SDM di Unit Profesi SDM dalam Menghadapi Era MEA, Jurnal Manajemen IKM, Vol. 13, No.1, :1-9.

Mahmud (2012), The Role of Organizational Development to Improve the Kordanian Universities Effectiveness, International Journal of Business and Management, Vol. 7, No. 19 : 76-83, Canadian Center of Science and Education.

Martina K, dkk ( 2012), Identification of Managerial Competencies in Knowledge Based Organization, Journal of Competitiveness, Vol. 4, No. 1 : 129-142.

Murwati, H (2013), Pengaruh Sertifikasi Profesi Guru terhadap Motivasi Kerja dan Kinerja Guru SMK di SMK Negeri se-Surakarta, Jurnal Pendidikan Bisnis dan Ekonomi (BISE), Vol. 1, No.1.

Pedoman Badan Nasional Sertifikasi (BNSP) No. 101-2005

Prasetya, dkk (2018), Metode dan Prosedur Pelaksanaan Rekrutmen Seleksi PT Bank Rakyat Indonesia (Persero) Tbk, Jumal Kompetensi, Vol. 12, No. 2.

Prasetyo, dkk (2018), Pengaruh Kompetensi Karyawn Terhadp Promosi Jabatan Pada PT Bank CIMB Niaga Tbk Bintaro Griya Niaga, Jurnal Widya Cipta, Vol. 2, No. 1.

Rahmayanty, N (2010), Manajemen Pelayanan Prima, Yogyakarta, Graha Ilmu.

Riesminingsih (2013), Pengaruh Kompetensi dan Motivasi Terhadap Kinerja Guru SMA YADIKA 3 Karang Tengah, Jurnal MIX, Vol. 3, No. 3 : 263-271.

Sahaka, A. dll, (2017), Sistem Rekruitmen Karyawan pada PT Bank Syariah Mandiri Cabang Bone, Jurnal Diskursus Islam, Vol. 5, No. 2.

Saskiawardani, N (2009), Program Sertifikasi Bankir Umum, Media Bankir, Ikatan Bankir Indonesia, Jakarta.

Shaputra, dkk (2015), Pengaruh Kompetensi, Komitmen, dan Pengembangan Karir Terhadap Kinerja Karyawan PT Bank Rakyat Indonesia (Persero) Kantor Wilayah Pekanbaru, Jurnal Tapak, Vol. 7, No.1. 
Silitonga, P (2007), Perbandingan Penerapan Sistem Sertifikasi Kompetensi di Indonesia dan di Negara-Negara Lain, Jurnal Panorama Nusantara, Vol. 2, No. 1.

Sugiyono (2016), Metode Penelitian Kuantitatif Kualitatif dan RED, Alfabeta, Bandung.

Suwarsi, dkk (2014), Implementation of Coumpetency Based Human Resource and Knowledge Management to Organizational Culture and Implication to Organizational Performance, International Journal of Human Resource Studies, Vol. 4, No. 3 : 255-268.

Tho' in, M (2016), Kompetensi Sumber Daya Manusia Bank Syariah Berdasarkan Prinsip-Prinsip Syariah Islam (Studi Kasus Pada Bank BNI Syariah Surakarta), Jurmal Ilmiah Ekonomi Islam, Vol. 2, No.02 .

Triana, H (2017), Pengembangan Kualitas SDM Indonesia dengan Sertifikasi Profesi, Jakarta, PT Gramedia Pustaka Utama.

Undang-Undang Ketenagakerjaan No. 13 Tahun 2003 Pasal 18

Wahyudi, F (2014), Peran Kompetensi Dalam meningkatkan Kinerja Pegawai Bagian Sosial Sekretariat Daerah Kabupaten Kutai Timur, eJoumal Administrative Reform, Vol. 2, No. 1.

Wirjoatmodjo, K (2017), Transformasi Digital Suatu Keniscayaan, Majalah Infobank, Jakarta.

Wulandari, dkk (2018), Identifikasi Kompetensi Manajerial Pada Level Manajemen Menengah dalam Industri Perbankan Indonesia, Jurnal Siasat Bisnis, Vol. 22, No. 1 : 20-31.

Yamu'alim (2015), Sertifikat Kompetensi Sebagai Standar Kompetensi Kerja, Jurnal Forum Manajemen, Vol. 6, No. 1.

Keywords: Acceptance; Frontliners; Certification; Competence. 